\title{
The Role of the Local Bone Marrow Renin-Angiotensin System in Multiple Myeloma
}

\author{
Multipl Myelomda Lokal Kemik Iliği Renin-Anjiyotensin Sisteminin Rolü
}

\author{
(D) Bülent Saka1, (D) Müge Sayitoğlu², (D) Zülal İstemihan¹, (D) M. Akif Karan1, (D) Nilgün Erten¹, (D) Öner Doğan³, (D) Uğur Özbek², \\ (D) Sema Genç4, (D) Cemil Taşçıŏlu11, (D) Sevgi Kalayoğlu-Beşışık1 \\ 1 istanbul University, Istanbul Faculty of Medicine, Department of Internal Medicine, istanbul, Turkey \\ 2 istanbul University, Aziz Sancar Institute of Experimental Research, Department of Genetics, Istanbul, Turkey \\ 3istanbul University, Istanbul Faculty of Medicine, Department of Pathology, Istanbul, Turkey \\ 4 istanbul University, Istanbul Faculty of Medicine, Department of Biochemistry, Istanbul, Turkey
}

\section{Abstract}

Objective: Angiotensin II promotes growth and angiogenesis via type 1 receptors (AGTR1) in certain tumors. In this study, we examine the bone marrow AGTR1 expression in multiple myeloma (MM) and its relationship with the regulation of angiogenesis and prognostic factors.

Materials and Methods: Bone marrow AGTR1 mRNA levels of $39 \mathrm{MM}$ patients and 15 healthy controls were analyzed with quantitative RTPCR. Immunohistochemical staining of the tissue vascular endothelial growth factor (VEGF), CD34, and factor VIIIrAg (fVIIIrAg) was used to assess bone marrow angiogenesis.

Results: Bone marrow samples of the patients showed increased VEGF, fVIIIrAg, and CD34 staining and higher AGTR1 expression levels when compared to controls. Patients with severe-diffuse bone marrow infiltration showed higher bone marrow VEGF, fVIIIrAg, CD34, and AGTR1 mRNA levels when compared to other patients.

Conclusion: AGTR1 expression was found positively correlated with plasma $\beta 2$-microglobulin level and patients with increased AGTR1 expression showed increased bone marrow CD34 levels.

Keywords: Multiple myeloma, Renin-angiotensin system, Angiotensin type 1a receptor

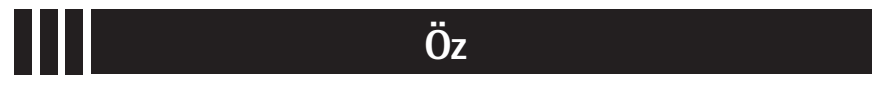

Amaç: Anjiyotensin II, bazı tümörlerde tip 1 reseptörleri (AGTR1) yoluyla bir büyüme promotörü veya anjiyojenik faktör olarak görev yapar. Bu çalışmada, multipl myelomda (MM) kemik iliği AGTR1 ekspresyonunu ve bunun anjiyogenez ve prognostik faktörlerin düzenlenmesi ile ilişkisini incelemekteyiz.

Gereç ve Yöntemler: Otuz dokuz MM hastası ve 15 sağlıklı kontrolde, kemik iliği AGTR1 mRNA düzeyleri kantitatif RT-PCR ile analiz edildi. Kemik iliği anjiogenezi, doku vasküler endotel büyüme faktörü (VEGF), CD34 ve faktör VIIIrAg'nın (fVIIIrAg) immünohistokimyasal ölçümü ile değerlendirildi.

Bulgular: Hastalar kontrollerle karşılaştırıldığında daha yüksek kemik iliği VEGF, fVIIIrAg, CD34 ve AGTR1 ekspresyon seviyelerine sahipti ve şiddetli yaygın kemik iliği infiltrasyonu olan hastalar diğer hastalara göre daha yüksek kemik iliği VEGF, fVIIIrAg, CD34 ve AGTR1 mRNA seviyeleri gösterdi.

Sonuç: AGTR1 ekspresyonu, plazma $\beta 2$-mikroglobulin seviyesi ile korele bulundu ve artan AGTR1 ekspresyonu olan hastalarda kemik iliği CD34 seviyelerinde artış görüldü.

Anahtar Sözcükler: Multipl myelom, Renin-anjiyotensin sistemi, Anjiyotensin tip 1a reseptörü

\section{Introduction}

Side effects of angiotensin-converting enzyme inhibitors (ACEIs) such as anemia and leukopenia indicate inhibitory effects of these drugs on normal bone marrow hematopoiesis. With previous data on locally acting growth factor-like effects of angiotensin II (ATII), Haznedaroglu et al. [1] and Haznedaroglu and Ozturk [2] first mentioned a local renin-angiotensin system (RAS) in the bone marrow. The possible role of the bone marrow RAS was later reported in acute myeloid leukemia [3,4]. Abali et al. [5] showed increased bone marrow angiotensin-converting enzyme (ACE) levels compared to serum ACE in acute leukemia.

๑Copyright 2019 by Turkish Society of Hematology

Turkish Journal of Hematology, Published by Galenos Publishing House

口:济四 Address for Correspondence/Yazışma Adresi: Bülent SAKA, M.D.,

İstanbul University, İstanbul Faculty of Medicine, Department of Internal Medicine, İstanbul, Turkey

Phone : +90 21241420 00/31478

E-mail : drsakab@yahoo.com ORCID-ID: orcid.org/0000-0001-5404-5579

This study was presented as a poster on February 26-March 1, 2009, at the XII. International Myeloma Workshop

Congress and published as an abstract in the Clinical Lymphoma, Myeloma \& Leukemia Journal at 2009;9:10.
Received/Geliş tarihi: December 03, 2018 Accepted/Kabul tarihi: April 25, 2019 
ATII was also related to angiogenesis, which could be inhibited with ACEI and ATII type 1a receptor (AGTR1) antagonists $[6,7,8]$. It can induce neovascularization due to increased expression of different growth factors (angiopoietin 2, vascular endothelial growth factor (VEGF), fibroblast growth factor, platelet-derived growth factor, transforming growth factor beta, and epidermal growth factor), nitric oxide synthase, and metalloproteinases [9]. Tamarat et al. [6] showed increased neovascularization with subcutaneous ATII injection in a rat model, which was found to be well correlated with serum VEGF and endothelial nitric oxide levels. AGTR1 antagonists and VEGF neutralizing antibodies completely prevented the ATII-induced angiogenesis. In another study, ATII was related to tumoral enlargement by inducing angiogenesis and malignant cell proliferation via AGTR1, while ACEI was shown to decrease cancer risk [8]. Egami et al. [10] compared rats with Agtr1+ and Agtr1- malignant melanoma and found decreased tumor angiogenesis and doubling time in Agtr1- rats, which resulted in increased survival rate. AGTR1 antagonists showed suppressed tumor growth in Agtr1+ rats.

The interaction between malignant plasma cells and the bone marrow microenvironment is important in the etiopathogenesis of multiple myeloma (MM). Increased angiogenesis was shown in the bone marrow microenvironment, which was related to disease progression, resistance to treatment, and worse prognosis [11]. Tumor growth and angiogenesis may result from various cytokines and factors. VEGF is the best characterized pro-angiogenic factor produced by myeloma cells. It also stimulates stromal cells to produce interleukin-6, which is a potent myeloma growth factor $[12,13]$.

The aim of this study was to find out any possible relationship between local bone marrow RAS activity and MM. Bone marrow RAS activities of patients were compared with their disease activity and bone marrow angiogenesis.

\section{Materials and Methods}

\section{Patients and Controls}

De novo MM patients $(n=39)$ without any previous treatment were enrolled in the study group. The control group $(n=15)$ included healthy bone marrow donors and those with normal bone marrow histology who were examined clinically for any other reason (Figure 1). Patients and controls taking drugs with possible effects on the RAS were excluded (ACE inhibitors, AGTR1 antagonists, beta blockers, spironolactone). Patients and controls with acute and/or chronic infectious diseases, inflammatory rheumatoid diseases, and any other cancer were also excluded. This study was approved by the Ethics Committee of İstanbul University İstanbul Medical Faculty (reference number 2008/305). Every patient included in the study provided signed informed consent.

\section{RNA Isolation and cDNA Synthesis}

Bone marrow samples were collected in 2-mL ethylene diamine tetraacetic acid tubes. Total RNA was isolated from white blood cells (OIAGEN, Germany). RNA quality and quantity were measured by spectrophotometer (ND-1000, NanoDrop Technologies, Inc., USA), and $1 \mu \mathrm{g}$ of total RNA was used. Random primers (20 $\mu \mathrm{M}$, Roche Diagnostics, Germany), $10 \mathrm{mM}$ dNTP set (Fermentas UAB, Lithuania), RiboLock RNase Inhibitor (20 $\mathrm{U} / \mu \mathrm{L}$, Fermentas), and Moloney murine leukemia virus reverse transcriptase (200 U/ $\mu \mathrm{L}$, Fermentas) were used for cDNA synthesis. cDNA samples were stored at $-20^{\circ} \mathrm{C}$.

\section{Quantitative Real-Time Polymerase Chain Reaction Analysis}

Real-time quantitative PCR was performed with a LightCycler 480 instrument (Roche Applied Sciences, Germany) (Table 1). Real-time amplification was performed with LightCycler 480 Probe Master Mix (Roche) according to the manufacturer's protocol. Real-time amplification was performed with a final

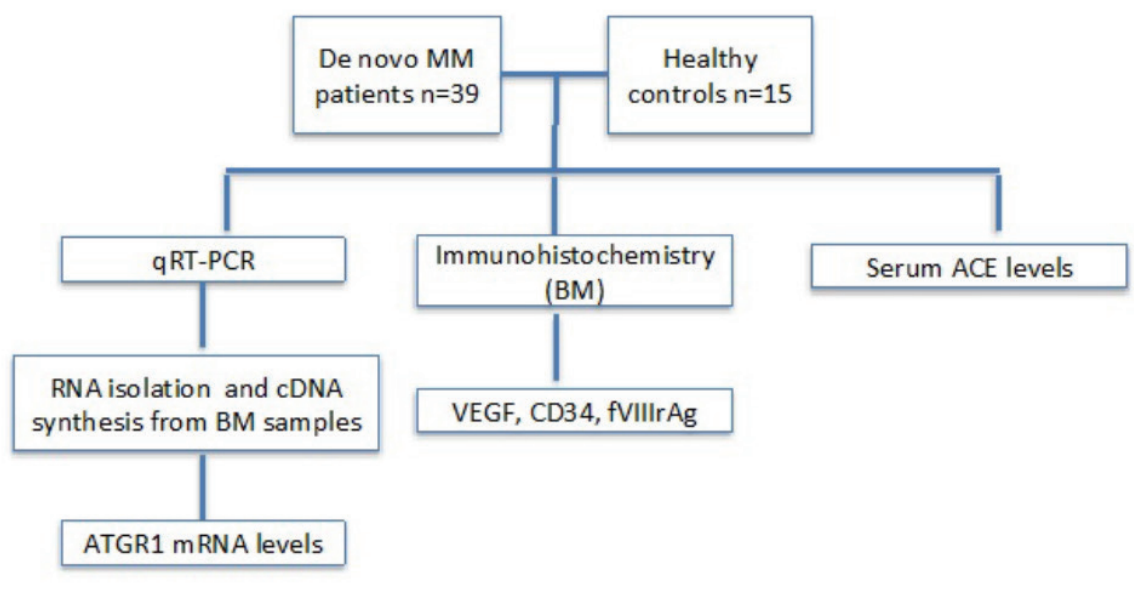

Figure 1. Flowchart of the study.

AGTR1 mRNA: Angiotensin II type 1a receptor mRNA relative expression level, VEGF: vascular endothelial growth factor, MM: multiple myeloma, qRT$P C R$ : quantitative real-time polymerase chain reaction, ACE: angiotensin-converting enzyme. 
reaction mixture of $20 \mu \mathrm{L}$ containing $5 \mu \mathrm{M}$ of each primer, $0.5 \mu \mathrm{M}$ of each probe, LightCycler 480 Probe Master Mix, and $100 \mathrm{ng} / \mu \mathrm{L}$ of cDNA. The three most stable genes (B-ACTIN, CYCLOPHILIN $A$, and $A B L$ ) were selected for normalization by geNorm software V3.4 (University of Liege, Belgium) (Table 1). Each sample was studied in duplicate and all runs were repeated twice. The PCR protocol was as follows: initial denaturation at $95^{\circ} \mathrm{C}$ for $7 \mathrm{~min}$, and amplification for $5 \mathrm{~s}$ at $95^{\circ} \mathrm{C}, 10 \mathrm{~s}$ at $60^{\circ} \mathrm{C}$, and $10 \mathrm{~s}$ at $72{ }^{\circ} \mathrm{C}$ for $45 \mathrm{cycles}$. The $\Delta \Delta \mathrm{Ct}$ method was used to calculate relative expressions [14].

\section{Immunohistochemical Studies}

Bone marrow angiogenesis was evaluated with the immunohistochemical measurement of tissue VEGF (Figure 2), CD34 (Figure 3), and factor VIIIrAg (fVIIIrAg) indexes.

Bone marrow biopsy samples were fixed in formalin (10\%) and then embedded into tissue paraffin blocks. After staining with hematoxylin and eosin, they were examined under a microscope. Tissue samples were incubated with anti-VEGF mouse monoclonal antibodies (clone G153-694) at $2 \mu \mathrm{g}$ antibody/mL dilution. Immunocytochemical streptavidin-biotin peroxidase complex was used in the next stage, followed by diaminobenzidine chromogen for visualization of peroxidase reaction. Immunohistochemical staining activity was estimated semiquantitatively by using the immunoreactive score [15]. Scores were given to intensity of the reaction (stain) (0 to 3 ) and percentage of the cells with positive reaction (0 to 4 ). The

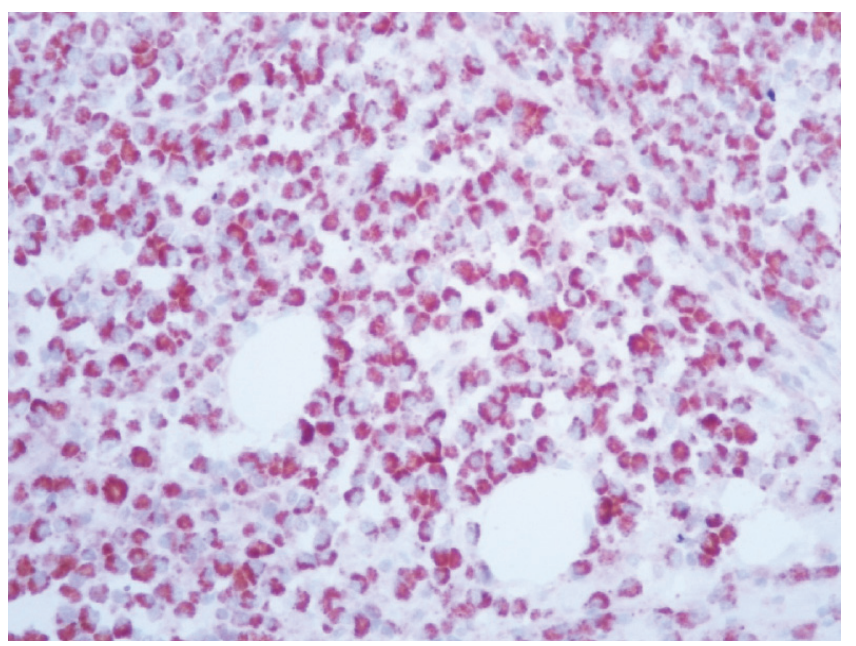

Figure 2. Bone marrow anti-vascular endothelial growth factor antibody, AEC chromogen, 400x. final score was then obtained with the multiplication of both scores (0 to 12) (Table 2).

Staining of vascular endothelial cells with anti-CD34 murine monoclonal antibodies (Clone QBEnd/10, NeoMarkers, USA) at $1 / 100$ dilution was also used to show bone marrow angiogenesis as described by Perez-Atayde et al. [16]. Bone marrow biopsy samples were examined at $80^{x}$ magnification and five distinct fields were selected for evaluation. Mean number of CD34-stained vascular structures was defined as number of vessels $/ \mathrm{mm}^{2}$. Factor VIIIrAg was also used to demonstrate bone marrow angiogenesis (Table 3 ).

Serum ACE levels of both groups were measured by sandwich ELISA method. One microplate was coated with an ACE-specific monoclonal antibody. Standards and serum samples were put in small Eppendorf tubes and ACE was bound with immobilized antibodies. After unbound materials were washed out of the wells, ACE-specific enzyme-linked polyclonal antibody was added to the tubes. Later, unbound antibody-enzyme particles were washed out, followed by the addition of substrate solution to samples. Color changes that occurred in the Eppendorf tubes were parallel to the ACE levels.

\section{Statistical Analysis}

SPSS 15.0 was used to analyze data. Continuous variables were described with the use of statistical characteristics (means, standard deviations, median). Discrete variables were described as counts and percentages. The Kolmogorov-Smirnov test was

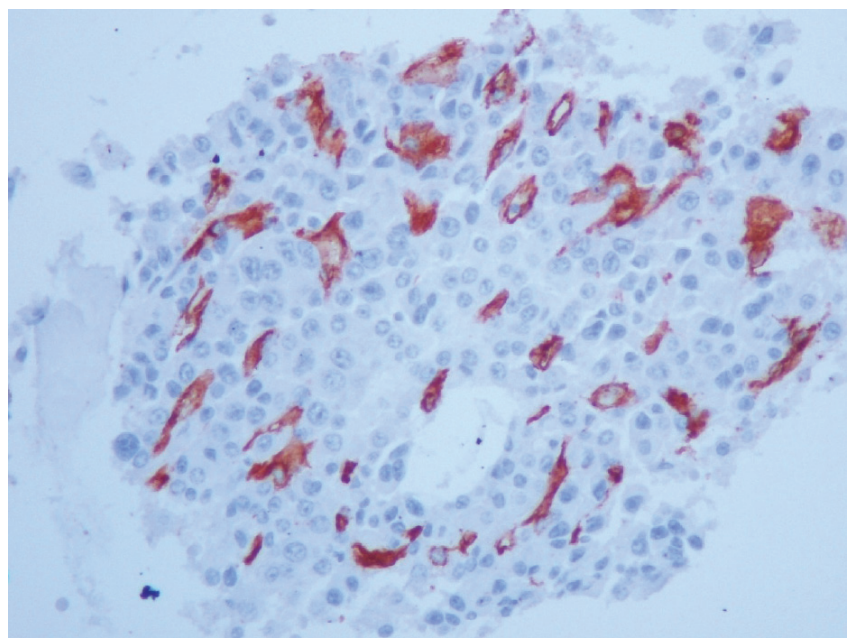

Figure 3. Bone marrow anti-CD34 antibody, AEC chromogen, 400x.

\begin{tabular}{|c|c|c|c|}
\hline Gene & Forward $\left(5^{\prime} \rightarrow 3^{\prime}\right)$ & Reverse $\left(5^{\prime} \rightarrow 3^{\prime}\right)$ & UPL probe no. \\
\hline AGTR1 & ccattatgagtcccaaaattcaa & aaaggaaacaggaaacccagta & 23 \\
\hline CYPA & cctaaagcatacgggtcctg & cactttgcсааасассасаt & 48 \\
\hline B ACTIN & aggcccctctgaacccta & ggggtgttgaaggtctcaaa & $\beta$ ACTIN \\
\hline
\end{tabular}


used to analyze distribution of the variables. Independent samples t-tests, Mann-Whitney U tests, and Pearson correlation analyses were used during evaluation of the results. A value of $p \leq 0.05$ was considered statistically significant.

\section{Results}

\section{AGTR1 mRNA Expression in MM Cases and Controls}

Thirty-nine MM patients (male/female: 20/19) were enrolled in the study. The control group included five healthy bone marrow donors and 10 people with normal cellular bone marrow biopsies who were examined for any other reason (male/female: 8/7). Mean ages of the patients and controls were

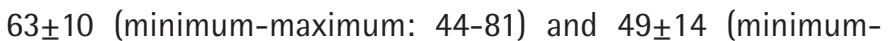
maximum: 27-80) years, respectively. Clinical characteristics of the patients are given in Table 4. Bone marrow VEGF, CD34, and fVIIIrAg and AGTR1 mRNA expression levels of the patients are given in Table 5. MM patients had higher bone marrow VEGF, CD34, and fVIIIrAg levels and increased AGTR1 mRNA expression levels when compared to controls (Table 6). Patients with severe-diffuse bone marrow infiltration patterns showed higher bone marrow VEGF, CD34, and fVIIIrAg levels and higher bone marrow AGTR1 mRNA expression when compared to others with mild-patchy infiltration patterns (Table 7; Figure 4). Plasma $\beta 2$-microglobulin (B2M) concentrations of the patients were found to be well correlated with their bone marrow AGTR1 mRNA expression levels (Figure $5 ; p=0.002$ ). No association was found between disease stage and bone marrow AGTR1 mRNA expression ( $p=0.760$ ). Serum ACE levels of MM patients did not show any significant difference when compared to the control group (Student's t-test).

Table 2. Estimation of the bone marrow vascular endothelial growth factor index with immunoreactive score.

\begin{tabular}{|l|l|l|}
\hline Score & Positive cells (\%) & $\begin{array}{l}\text { Intensity of the } \\
\text { reaction }\end{array}$ \\
\hline 0 & Negative & Negative \\
\hline 1 & $<10$ & Weak \\
\hline 2 & $10-50$ & Moderate \\
\hline 3 & $51-80$ & Strong \\
\hline 4 & $>81$ & Very strong \\
\hline
\end{tabular}

Patients with higher AGTR1 mRNA expression showed increased bone marrow CD34 ( $p=0.011$, Student's t-test). Similarly, patients with higher AGTR1 mRNA expression showed increased bone marrow VEGF and fVIIIrAg indexes, although these did not reach statistical significance (VEGF: $p=0.088$, Mann-Whitney U test, fVIIIrAg: $p=0.345$, Student's t-test).

\section{Discussion}

The RAS has attracted attention because of its physiological and therapeutic potential. An extensive transcriptomic metaanalysis showed the expression patterns of RAS members in normal human tissues, including hematopoietic cells and bone marrow stem cells. AGT ligand was determined to be expressed in almost all tissue types, indicating its physiological importance. Bone marrow-derived cells have prominent expression of classical systemic RAS participants (AGT-REN-ACE-AGTR1) and they have almost the same expression patterns, indicating that transcriptional coordination may be preserved during cell lineage [17].

The RAS plays a role in hematopoietic stem cell plasticity. There is increasing evidence that the deregulated local bone marrow

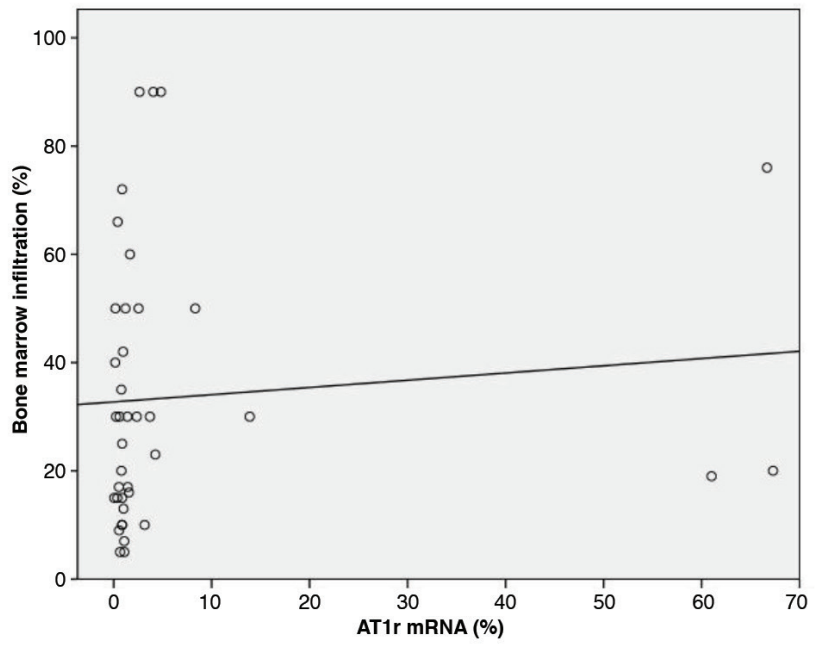

Figure 4. Correlation of the bone marrow infiltration ratio and AGTR1 mRNA expression of the patients.

AGTR1 mRNA: Angiotensin II type 1a receptor mRNA relative expression level.

Table 3. Bone marrow immunohistochemical studies of angiogenesis.

\begin{tabular}{|l|l|l|l|l|l|l|l|}
\hline $\begin{array}{l}\text { Primary } \\
\text { antibody }\end{array}$ & Producer & Antigen retrieval & $\begin{array}{l}\text { Primary } \\
\text { antibody } \\
\text { dilution }\end{array}$ & $\begin{array}{l}\text { Incubation } \\
\text { time }\end{array}$ & $\begin{array}{l}\text { Incubation } \\
\text { temperature }\end{array}$ & Amplification system & Chromogen \\
\hline VEGF & NeoMarkers & $\begin{array}{l}\text { EDTA irradiation in } \\
\text { microwave oven }\end{array}$ & $1 / 50$ & $1 \mathrm{~h}$ & $\begin{array}{l}\text { Room } \\
\text { temperature }\end{array}$ & $\begin{array}{l}\text { Biotin-streptavidin- } \\
\text { peroxidase }\end{array}$ & $\begin{array}{l}\text { AEC } \\
\text { CD34 }\end{array}$ \\
\hline Factor VIIIrAg & NeoMarkers & $\begin{array}{l}\text { Boiling in citrate buffer } \\
\text { under high pressure }\end{array}$ & $1 / 50$ & $1 \mathrm{~h}$ & $\begin{array}{l}\text { Room } \\
\text { temperature }\end{array}$ & $\begin{array}{l}\text { Biotin-streptavidin- } \\
\text { peroxidase }\end{array}$ & AEC \\
under high pressure & $1 / 50$ & $1 \mathrm{~h}$ & $\begin{array}{l}\text { Room } \\
\text { temperature }\end{array}$ & $\begin{array}{l}\text { Biotin-streptavidin- } \\
\text { peroxidase }\end{array}$ & AEC \\
\hline
\end{tabular}


RAS could play a role in malignant transformation by increasing cellular proliferation and differentiation. ACE induces bone marrow stem cells to enter the $\mathrm{S}$-phase through increasing hydrolysis of acetyl-N-Ser-Asp-Lys-Pro (AcSDKP), which inhibits the proliferation of bone marrow stem cells $[18,19]$. Conversely, ACEls increase plasma AcSDKP and downregulate hematopoiesis [20]. ACEl treatment significantly decreased the hematocrit level of a patient with polycythemia vera [21].

Wulf et al. $[3,4]$ showed renin-like activity in leukemic blast cells of a patient and isolated renin-like peptide from myeloblasts.

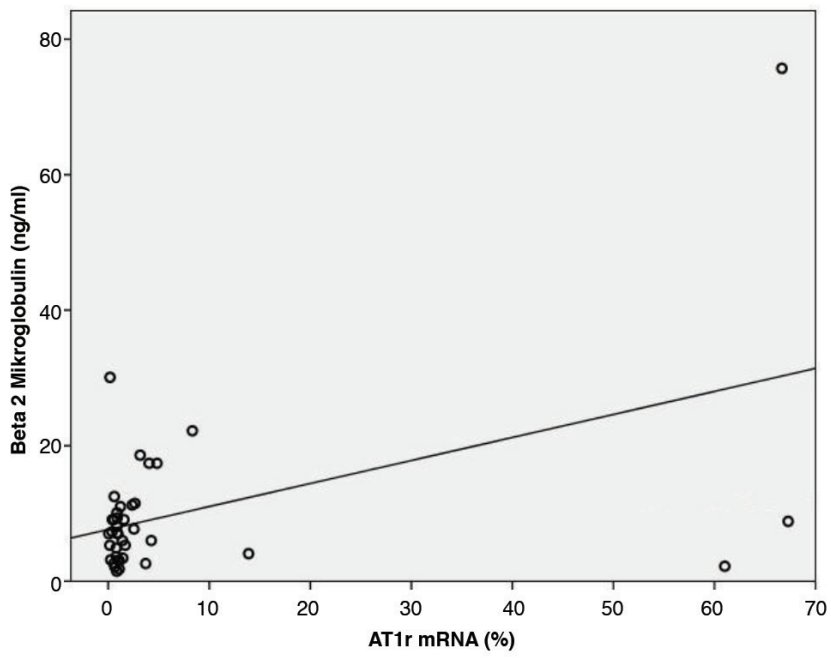

Figure 5. Correlation of the bone marrow AGTR1 mRNA expression and serum $\beta 2$-microglobulin levels of the patients.

AGTR1 mRNA: Angiotensin II type 1a receptor mRNA relative expression level.

\begin{tabular}{|l|l|}
\hline \multicolumn{2}{|l|}{ Table 4. Clinical characteristics of the patients. } \\
\hline Age (years) & $\begin{array}{l}\text { Mean } \pm \text { SD } \\
\text { (minimum - maximum) }\end{array}$ \\
\hline Male & $64 \pm 10(44-81)$ \\
Female & $63 \pm 9(45-80)$ \\
Total & $63 \pm 10(44-81)$ \\
\hline Durie-Salmon classification & No. of patients \\
\hline IA & 2 \\
IIA & 9 \\
IIB & 2 \\
IIIA & 16 \\
IIIB & 10 \\
\hline Paraprotein type & No. of patients \\
\hline IgG & 24 \\
IgA & 7 \\
IgD & 2 \\
Light chain & 6 \\
\hline Bone marrow infiltration pattern & No. of patients \\
\hline Patchy & 15 \\
Diffuse & 24 \\
\hline SD: Standard deviation, Ig: immunoglobulin. \\
\hline
\end{tabular}

Abali et al. [5] compared serum and bone marrow ACE concentrations of newly diagnosed acute leukemia patients and found significant increase in the latter. Serum ACE levels were found correlated with bone marrow infiltration rate and the number of blasts in the peripheral blood. RAS members' expressions were detected in different myeloid blast cells $[22,23]$. RAS and NOTCH pathways are in communication, and the RBP-J gene (recombination signal binding protein for immunoglobulin kappa J region) is an important transcriptional regulator of the NOTCH pathway. An RBP-J-deleted mouse model showed Ren expression leading to leukemogenesis in B-cell progenitors. Moreover, there are limited data showing RBP-J gene mutations in leukemia patients [24,25]. Serum ACE was found increased in MM patients and local RAS components were also found in the following studies [26,27].

ATII plays a fundamental role in controlling cardiovascular function and renal homeostasis. It has many physiologic effects other than regulating vascular tone, such as hormone secretion, tissue growth, and neural activity. It has four receptors. AGTR1 stimulation activates intracellular pathways that finally lead to vasoconstriction, inflammation, and proliferation [9]. Like other cytokines, ATII was shown to use the JAK-STAT pathway (JAnus or Just Another Kinase-Signal Transducers and Activators of Transcription) in the regulation of hematopoiesis [28]. Gomez et al. [29] revealed the ability of rat leukocytes to produce angiotensinogen and ATII, and Crabos et al. [30] found Agtr 1 on thrombocytes. Rodgers et al. [31] showed Agtr1 on CD34+CD38- and CD34+CD38+ cells, lymphocytes, and bone marrow stromal cells, and they reported increased bone marrow stem cell proliferation with ATII that was inhibited with the AGTR1 antagonist losartan. Mrug et al. [32] reported similar effects of the local bone marrow RAS on the erythroid cell lineage. Jokubaitis et al. [33] identified a 160-kDa cell surface glycoprotein, BB9, which is found on hematopoietic stem cells (HSCs) throughout hematopoietic development, even at the earliest definitive phases. They demonstrated that BB9 monoclonal $A b$ identifies the somatic form of angiotensinconverting enzyme (ACE/CD143), which suggested its expression by HSCs from primitive phases to adulthood. ACE/CD143 may thus play a role in the regulation of hematopoietic cells.

According to our results, the bone marrow AGTR1 expression of our patients showed positive correlation with their bone marrow infiltration pattern and serum B2M levels. Serum B2M level and the morphology of myeloma cells are reliable prognostic factors in MM. Moreover, serum B2M was found as the most important parameter in predicting high-risk patients $[34,35]$. The positive correlation between bone marrow AGTR1 mRNA levels, bone marrow morphology, and plasma B2M showed that bone marrow AGTR1 expression can give information about prognosis in MM. 


\begin{tabular}{|c|c|c|c|c|c|c|c|c|c|}
\hline No. & Sex & Age & PP & Stage & B2M & VEGF & CD34 & fVIIIrAg & AGTR1 mRNA \\
\hline 1 & M & 73 & IgG kарра & IIIB & \begin{tabular}{|l}
9.08 \\
\end{tabular} & 12 & 21.5 & 50.2 & \begin{tabular}{|l|l|}
1.57 &
\end{tabular} \\
\hline 2 & M & 76 & IgG lambda & IIIB & \begin{tabular}{|l|}
9.30 \\
\end{tabular} & 12 & 57.6 & 74.0 & \begin{tabular}{|l|l|}
0.87 &
\end{tabular} \\
\hline 3 & M & 75 & IgA lambda & IIIA & \begin{tabular}{|l|}
11.00 \\
\end{tabular} & 12 & 153.0 & 54.8 & 1.21 \\
\hline 4 & $\mathrm{~F}$ & 64 & IgG kappa & IIA & 1.45 & 6 & 33.0 & 19.4 & 0.85 \\
\hline 5 & $\mathrm{~F}$ & 60 & IgG lambda & IIIA & \begin{tabular}{|l|}
11.49 \\
\end{tabular} & 8 & 50.0 & 36.8 & 2.64 \\
\hline 6 & $M$ & 63 & IgG kappa & IIIA & 3.63 & 12 & 76.0 & 188.2 & 0.79 \\
\hline 7 & $\mathrm{~F}$ & 80 & IgG kappa & IIA & 8.09 & 3 & 20.0 & 23.4 & 0.86 \\
\hline 8 & $\mathrm{M}$ & 69 & IgG kарра & IIIA & 8.83 & 12 & 76.0 & 118.3 & 67.29 \\
\hline 9 & $M$ & 54 & IgG kappa & IIIA & 3.16 & 12 & 57.3 & 26.0 & 0.24 \\
\hline 10 & $M$ & 55 & IgG kappa & IIIB & 22.20 & 8 & 42.2 & 36.4 & 8.33 \\
\hline 11 & $M$ & 74 & Lambda & IIIA & 7.00 & 3 & 44.3 & 23.0 & 0.06 \\
\hline 12 & M & 45 & IgG kappa & IIIB & \begin{tabular}{|l|}
9.10 \\
\end{tabular} & 8 & 50.7 & 46.7 & 0.41 \\
\hline 13 & $M$ & 58 & $\lg \mathrm{A}$ kарра & IIA & 1.80 & 12 & \begin{tabular}{|l|}
112.0 \\
\end{tabular} & 77.6 & 1.084 \\
\hline 14 & $\mathrm{~F}$ & 70 & IgG kappa & IIA & 4.90 & 8 & 44.0 & 14.5 & 0.79 \\
\hline 15 & $\mathrm{~F}$ & 45 & IgG kappa & IIIA & 2.60 & 8 & 42.0 & 29.8 & 0.55 \\
\hline 16 & $\mathrm{~F}$ & 65 & IgG lambda & IIIA & 7.30 & 12 & 68.0 & 56.7 & 0.38 \\
\hline 17 & $M$ & 76 & IgG lambda & IA & 2.12 & .8 & .52 .0 & 52.5 & 0.66 \\
\hline 18 & $M$ & 55 & IgG kappa & IIB & 10.10 & 12 & 41.8 & 13.4 & 0.86 \\
\hline 19 & $M$ & 60 & IgG lambda & IIIA & 4.06 & 8 & 53.0 & 20.0 & 13.88 \\
\hline 20 & $\mathrm{~F}$ & 51 & Kappa & IIIB & 75.70 & 12 & 80.7 & 73.6 & 66.67 \\
\hline 21 & $M$ & 44 & IgG kappa & IIIB & \begin{tabular}{|l|}
17.40 \\
\end{tabular} & 12 & 83.8 & 65.4 & 4.83 \\
\hline 22 & $M$ & 81 & IgG kарра & IIIA & 5.30 & 12 & 126.5 & 23.2 & 1.67 \\
\hline 23 & $\mathrm{~F}$ & 75 & IgG lambda & IA & 2.60 & 8 & 36.6 & 52.4 & 3.70 \\
\hline 24 & $\mathrm{~F}$ & 57 & Kappa & IIIB & 30.09 & 6 & 52.8 & 46.0 & 0.18 \\
\hline 25 & $\mathrm{~F}$ & 52 & IgD lambda & IIIA & 5.30 & 12 & 47.8 & 51.3 & 0.16 \\
\hline 26 & $\mathrm{~F}$ & 73 & Kaрра & IIIA & 6.00 & 12 & 84.0 & 63.5 & 4.25 \\
\hline 27 & $M$ & 57 & IgA kappa & IIB & 9.10 & 6 & 24.6 & 24.3 & 0.54 \\
\hline 28 & $\mathrm{~F}$ & 67 & IgA lambda & IIA & 2.20 & 12 & 50.6 & 18.4 & 61.02 \\
\hline 29 & $\mathrm{~F}$ & 73 & IgA kappa & IIIA & 6.00 & 12 & 64.6 & 45.5 & 1.40 \\
\hline 30 & $\mathrm{~F}$ & 62 & IgD lambda & IIIA & 7.70 & 8 & 43.4 & 32.4 & 2.54 \\
\hline 31 & $\mathrm{~F}$ & 60 & IgG kappa & IIIB & 7.05 & 6 & 20.0 & 20.0 & 0.87 \\
\hline 32 & $\mathrm{~F}$ & 68 & Карра & IIA & \begin{tabular}{|l|}
11.23 \\
\end{tabular} & 8 & 95.4 & 89.3 & 2.36 \\
\hline 33 & $\mathrm{~F}$ & 59 & IgG kappa & IIA & 3.40 & 12 & 52.8 & 57.0 & 1.44 \\
\hline 34 & $\mathrm{M}$ & 64 & IgG kappa & IIA & 3.00 & 12 & 110.0 & 77.7 & 1.08 \\
\hline 35 & $M$ & 68 & IgA kappa & IIIA & 12.50 & 12 & 96.0 & 84.0 & 0.59 \\
\hline 36 & $\mathrm{~F}$ & 54 & IgG lambda & IIIA & 7.00 & 8 & 44.4 & 42.0 & 0.96 \\
\hline 37 & $\mathrm{~F}$ & 62 & IgA lambda & IIIB & 17.40 & 12 & 122.4 & 133.0 & 4.04 \\
\hline 38 & $M$ & 65 & Lambda & IIA & 3.10 & 12 & 62.4 & 52.3 & 1.01 \\
\hline 39 & M & 58 & IgG lambda & IIIB & \begin{tabular}{|l|}
18.60 \\
\end{tabular} & 4 & 29.0 & 26.0 & 3.16 \\
\hline
\end{tabular}

Increased bone marrow VEGF, CD34, and fVIIIrAg indexes in our patients reflected neovascularization. Advancing age is associated with the development of vascular endothelial dysfunction. Vascular oxidative stress increases with age as a consequence of greater production of reactive oxygen species (e.g., superoxide) without a compensatory increase in antioxidant defenses. In our study, the control group seemed to be younger than the MM group (range: 27-80 years), but 


\begin{tabular}{|c|c|c|c|}
\hline & Patients & Controls & p-value \\
\hline VEGF index & $10 \pm 3$ & $2 \pm 1$ & $<0.001$ \\
\hline CD34 (no. of vessels) & $62.37 \pm 31.81$ & $38.55 \pm 17.26$ & 0.001 \\
\hline Factor VIIIrAg (U/mL) & $52.28 \pm 35.96$ & $28.09 \pm 14.49$ & 0.001 \\
\hline AGTR1 mRNA & $6.82 \pm 17.22$ & $1.17 \pm 1.09$ & 0.044 \\
\hline \multicolumn{4}{|c|}{$\begin{array}{l}\text { AGTR1 mRNA: Angiotensin II type 1a receptor mRNA relative expression level, VEGF: } \\
\text { vascular endothelial growth factor. }\end{array}$} \\
\hline
\end{tabular}

Table 7. Angiogenesis factors and AGTR1 mRNA expression levels according to bone marrow infiltration pattern of the patients.

\begin{tabular}{|l|l|l|l|}
\hline & $\begin{array}{l}\text { Mild-patchy } \\
\text { infiltration }\end{array}$ & $\begin{array}{l}\text { Severe- } \\
\text { diffuse } \\
\text { infiltration }\end{array}$ & p-value \\
\hline VEGF index & $8 \pm 3$ & $10 \pm 2$ & 0.017 \\
\hline CD34 (no. of vessels) & $47.24 \pm 24.92$ & $69.36 \pm 32.61$ & 0.045 \\
\hline Factor VIIIrAg (U/mL) & $37.16 \pm 21.44$ & $59.25 \pm 39.39$ & 0.032 \\
\hline AGTR1 mRNA & $0.81 \pm 0.32$ & $9.82 \pm 20.56$ & 0.035 \\
\hline $\begin{array}{l}\text { AGTR1 mRNA: Angiotensin II type 1a receptor mRNA relative expression level, VEGF: } \\
\text { vascular endothelial growth factor. }\end{array}$ \\
\hline
\end{tabular}

was within the age range at which MM develops. Patients with higher AGTR1 expression showed increased bone marrow CD34 index. In our opinion, the statistically nonsignificant increase in the bone marrow VEGF and fVIIIrAg indexes of these patients was related to the number of subjects enrolled in the study.

Bone marrow AGTR1 mRNA expression was 2\%-4\% in 5 patients and $>4 \%$ in 8 patients. Three patients had extremely high levels of expression $(67.29 \%, 66.67 \%$, and $61.02 \%)$ when compared to others. The first patient was a 69-year-old man with IgG kappa light chain MM of stage 3. He had 30\% bone marrow infiltration and his serum monoclonal band, lactate dehydrogenase (LDH), and B2M were $5.28 \mathrm{~g} / \mathrm{dL}, 412 \mathrm{IU} / \mathrm{L}$, and $8.83 \mathrm{ng} / \mathrm{mL}$, respectively. The second patient was a 51-year-old woman with kappa light chain secreting disease of stage 3 . Her laboratory analysis revealed overt disease activity (76\% bone marrow infiltration, serum monoclonal band $6.9 \mathrm{~g} / \mathrm{dL}, \mathrm{LDH} 696 \mathrm{IU} / \mathrm{L}$, and B2M 75.76 $\mathrm{ng} / \mathrm{mL}$ ). The third patient was a 67-year-old woman with IgA lambda light chain secreting disease of stage 2 . She had mild disease activity at diagnosis (21\% bone marrow infiltration, serum monoclonal band $1.94 \mathrm{~g} / \mathrm{dL}, \mathrm{LDH} 264 \mathrm{IU} / \mathrm{L}$, and B2M 2.24 $\mathrm{ng} / \mathrm{mL}$ ). Bone marrow VEGF, CD34, and fVIIIrAg indexes of these three patients were also found to be significantly increased.

Only 3 control subjects showed 2\%-4\% bone marrow AGTR1 mRNA expression. Two of them were under medical examination for another reason and showed normocellular bone marrow histology, and the third one was a healthy bone marrow donor. Moreover, they had relatively low levels of bone marrow VEGF, CD34, and fVIIIrAg indexes when compared with MM patients.
A clinically relevant aspect of the interactions of $\mathrm{MM}$ plasma cells in the bone marrow microenvironment is neovascularization, a constant hallmark of disease progression. Myeloma plasma cells also induce angiogenesis indirectly via recruitment and activation of stromal inflammatory cells (i.e. macrophages and mast cells) to secrete their own angiogenic factors. RAS signaling pathway mutations have been reported in newly diagnosed MM cases and even more so in relapsed/refractory MM $[36,37]$, which could correlate with ACE expression level. Both findings may encourage the use of ACEls or mitogen-activated protein kinase inhibitors in MM.

\section{Study Limitations}

The limitation of this study was the low number of MM patients enrolled, which was caused by the planned time schedule and the difficulty of finding de novo myeloma patients.

\section{Conclusion}

Bone marrow AGTR1 expression can give information about bone marrow morphology and can predict disease progression in MM. Further studies are needed to ascertain such an association.

\section{Ethics}

Ethics Committee Approval: The study was approved by the Ethical Commitee of İstanbul University, İstanbul Faculty of Medicine (2008/305), and every patient included in the study signed an informed consent.

\section{Authorship Contributions}

Surgical and Medical Practices: B.S., M.S., Z.I., S.K.B., M.A.K. N.E., C.T.; Concept: B.S., M.S., Z.I., S.K.B., M.A.K., N.E., C.T., U.O.; Design: B.S., S.K.B., M.S., U.Ö., Ö.D.; Data Collection or Processing: B.S., S.K.B., M.S., U.Ö., Ö.D., S.G., M.A.K., N.E., C.T., Z.I.; Analysis or Interpretation: B.S., S.K.B., M.S., U.Ö., Ö.D., S.G., Z.I.; Literature Search: B.S., S.K.B., B.S., S.K.B., M.S., Z.I., Writing: B.S., S.K.B., M.S., z.i.

Conflict of Interest: The authors of this paper have no conflicts of interest, including specific financial interests, relationships, and/or affiliations relevant to the subject matter or materials included.

Financial Disclosure: This work was supported by the Scientific and Technological Research Council of Turkey (TÜBITAK) under project no. $105 S 432$.

\section{References}

1. Haznedaroglu IC, Tuncer S, Gürsoy M. A local renin-angiotensin system in the bone marrow. Med Hypotheses 1996;46:507-510.

2. Haznedaroglu IC, Oztürk MA. Towards the understanding of the local hematopoietic bone marrow renin-angiotensin system. Int J Biochem Cell Biol 2003;35:867-880 
3. Wulf GG, Jahns-Streubel G, Strutz F, Basenau D, Hüfner M, Buske C, Wörmann B, Hiddemann W. Paraneoplastic hypokalemia in acute myeloid leukemia: a case of renin activity in AML blast cells. Ann Hematol 1996;73:139-141.

4. Wulf GG, Jahns-Streubel G, Nobiling R, Strutz F, Hemmerlein B, Hiddemann W, Wörmann B. Renin in acute myeloid leukaemia blasts. Br J Haematol 1998;100:335-337.

5. Abali H, Haznedaroglu IC, Goker H, Celik I, Ozatli D, Koray Z, Caglar M. Circulating and local bone marrow renin-angiotensin system in leukemic hematopoiesis: preliminary evidences. Hematology 2002;7:75-82.

6. Tamarat R, Silvestre JS, Durie M, Levy BI. Angiotensin II angiogenic effect in vivo involves vascular endothelial growth factor- and inflammation-related pathways. Lab Invest 2002;82:747-756.

7. Muramatsu M, Katada J, Hayashi L, Majima M. Chymase as a proangiogenic factor. A possible involvement of chymase-angiotensin-dependent pathway in the hamster sponge angiogenesis model. J Biol Chem 2000;275:5545-5552.

8. Lever AF, Hole DJ, Gillis CR, McCallum IR, McInnes GT, MacKinnon PL, Meredith PA, Murray LS, Reid JL, Robertson JW. Do inhibitors of angiotensin-I-converting enzyme protect against risk of cancer? Lancet 1998;352:179-184.

9. Escobar E, Rodríguez-Reyna TS, Arrieta O, Sotelo J. Angiotensin II, cell proliferation and angiogenesis regulator: biologic and therapeutic implications in cancer. Curr Vasc Pharmacol 2004;2:385-399.

10. Egami K, Murohara T, Shimada T, Sasaki K, Shintani $S$, Sugaya T, Ishii M, Akagi T, Ikeda H, Matsuishi T, Imaizumi T. Role of host angiotensin II type 1 receptor in tumor angiogenesis and growth. J Clin Invest 2003;112:67-75.

11. Munshi NC, Wilson C. Increased bone marrow microvessel density in newly diagnosed multiple myeloma carries a poor prognosis. Semin Oncol 2001;28:565-569.

12. Vacca A, Ribatti $D$, Roncali $L$, Ranieri G, Serio G, Silvestris $F$, Dammacco $\mathrm{F}$. Bone marrow angiogenesis and progression in multiple myeloma. $\mathrm{Br} \mathrm{J}$ Haematol 1994;87:503-508.

13. Vacca A, Ria R, Ribatti D, Semeraro F, Djonov V, Di Raimondo F, Dammacco F. A paracrine loop in the vascular endothelial growth factor pathway triggers tumor angiogenesis and growth in multiple myeloma. Haematologica 2003;88:176-185.

14. Livak KJ, Schmittgen TD. Analysis of relative gene expression data using realtime quantitative PCR and the $2^{-} \Delta \Delta C_{T}$ method. Methods 2001;25:402-408.

15. Remmele W, Stegner HE. Recommendation for uniform definition of an immunoreactive score (IRS) for immunohistochemical estrogen receptor detection (ER-ICA) in breast cancer tissue. Pathologe 1987;8:138-140.

16. Perez-Atayde AR, Sallan SE, Tedrow U, Connors $S$, Allred E, Folkman J. Spectrum of tumor angiogenesis in the bone marrow of children with acute lymphoblastic leukemia. Am J Pathol 1997;150:815-821.

17. Nehme A, Cerutti C, Dhaouadi N, Gustin MP, Courand PY, Zibara K, Bricca G. Atlas of tissue renin-angiotensin-aldosterone system in human: a transcriptomic meta-analysis. Sci Rep 2015;5:10035.

18. Rousseau-Plasse A, Lenfant M, Potier P. Catabolism of the hemoregulatory peptide $\mathrm{N}$-acetyl-Ser-Asp-Lys-Pro: a new insight into the physiological role of the angiotensin-I-converting enzyme $\mathrm{N}$-active site. Bioorg Med Chem 1996:4:1113-1119.

19. Li J, Volkov L, Comte L, Herve P, Praloran V, Charbord P. Production and consumption of the tetrapeptide AcSDKP, a negative regulator of hematopoietic stem cells, by hematopoietic microenvironmental cells. Exp Hematol 1997;25:140-146.

20. Azizi $M$, Rousseau $A$, Ezan $E$, Guyene $\Pi$, Michelet $S$, Grognet JM, Lenfant $M$, Corvol $P$, Ménard J. Acute angiotensin-converting enzyme inhibition increases the plasma level of the natural stem cell regulator $\mathrm{N}$-acetylserylaspartyl-lysyl-proline. J Clin Invest 1996;97:839-844.

21. Nomura $S$, Sugihara $T$, Tomiyama $T$, Kitano $Y$, Yawata $Y$, Osawa G. Polycythaemia vera: response to treatment with angiotensin-converting enzyme inhibitor. Eur J Haematol 1996;57:117-119.
22. Beyazit $Y$, Aksu S, Haznedaroglu IC, Kekilli M, Misirlioglu M, Tuncer $S$, Karakaya J, Koca E, Buyukasik Y, Sayinalp N, Goker H. Overexpression of the local bone marrow renin-angiotensin system in acute myeloid leukemia. J Natl Med Assoc 2007;99:57-63.

23. Haznedaroglu IC, Malkan UY. Local bone marrow renin-angiotensin system in the genesis of leukemia and other malignancies. Eur Rev Med Pharmacol Sci 2016;20:4089-4111.

24. Schuh A, Becq J, Humphray S, Alexa A, Burns A, Clifford R, Feller SM, Grocock R, Henderson $S$, Khrebtukova I, Kingsbury Z, Luo $S$, McBride $D$, Murray L, Menju T, Timbs A, Ross M, Taylor J, Bentley D. Monitoring chronic lymphocytic leukemia progression by whole genome sequencing reveals heterogeneous clonal evolution patterns. Blood 2012;120:4191-4196.

25. Belyea BC, Xu F, Pentz ES, Medrano S, Li M, Hu Y, Turner $S$, Legallo $R$, Jones CA, Tario JD, Liang P, Gross KW, Sequeira-Lopez ML, Gomez RA. Identification of renin progenitors in the mouse bone marrow that give rise to B-cell leukaemia. Nat Commun 2014;5:3273.

26. Albayrak M, Celebi H, Albayrak A, Sayilir A, Yesil Y, Balcik OS, Yokus O, Celik T. Elevated serum angiotensin converting enzyme levels as a reflection of bone marrow renin-angiotensin system activation in multiple myeloma. J Renin Angiotensin Aldosterone Syst 2012;13:259-264.

27. Uz B, Tatonyan SÇ, Sayitoğlu M, Erbilgin Y, Hatırnaz O, Aksu S, Büyükaşık Y, Sayınalp N, Göker H, Ozcebe Oi, Ozbek U, Haznedaroğlu IC. Local reninangiotensin system in normal hematopoietic and multiple myeloma-related progenitor cells. Turk J Hematol 2014;31:136-142.

28. Haznedaroglu IC, Arici M, Büyükaşik Y. A unifying hypothesis for the reninangiotensin system and hematopoiesis: sticking the pieces together with the JAK-STAT pathway. Med Hypotheses 2000;54:80-83.

29. Gomez RA, Norling LL, Wilfong N, Isakson P, Lynch KR, Hock R, Quesenberry P. Leukocytes synthesize angiotensinogen. Hypertension 1993;21:470-475.

30. Crabos $M$, Bertschin $S$, Bühler FR, Rogg $H$, Evéquoz D, Eberhard $M$, Erne P. Identification of AT1 receptors on human platelets and decreased angiotensin II binding in hypertension. J Hypertens 1993;11:230-231.

31. Rodgers KE, Xiong S, Steer R, diZerega GS. Effect of angiotensin II on hematopoietic progenitor cell proliferation. Stem Cells 2000;18:287-294.

32. Mrug M, Stopka T, Julian BA, Prchal JF, Prchal JT. Angiotensin II stimulates proliferation of normal early erythroid progenitors. J Clin Invest 1997; 100:2310-2314.

33. Jokubaitis VJ, Sinka L, Driessen R, Whitty G, Haylock DN, Bertoncello I, Smith I, Péault B, Tavian M, Simmons PJ. Angiotensin-converting enzyme (CD143) marks hematopoietic stem cells in human embryonic, fetal, and adult hematopoietic tissues. Blood 2008;111:4055-4063.

34. Durie BG, Stock-Novack D, Salmon SE, Finley P, Beckord J, Crowley J, Coltman CA. Prognostic value of pretreatment serum beta 2 microglobulin in myeloma: a Southwest Oncology Group Study. Blood 1990;75:823-830.

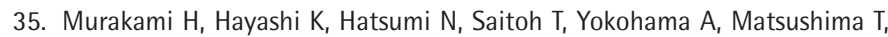
Tsukamoto N, Morita K, Karasawa M, Ogawara H, Sawamura M, Nojima Y. Risk factors for early death in patients undergoing treatment for multiple myeloma. Ann Hematol 2001;80:452-455.

36. Bezieau S, Devilder MC, Avet-Loiseau H, Mellerin MP, Puthier D, Pennarun E, Rapp MJ, Harousseau JL, Moisan JP, Bataille R. High incidence of $N$ and $\mathrm{K}$-Ras activating mutations in multiple myeloma and primary plasma cell leukemia at diagnosis. Hum Mutat 2001;8:212-224.

37. Walker BA, Boyle EM, Wardell CP, Murison A, Begum DB, Dahir NM, Proszek PZ, Johnson DC, Kaiser MF, Melchor L, Aronson LI, Scales M, Pawlyn C, Mirabella $F$, Jones JR, Brioli A, Mikulasova A, Cairns DA, Gregory WM, Quartilho A, Drayson MT, Russell N, Cook G, Jackson GH, Leleu X, Davies FE, Morgan GJ. Mutational spectrum, copy number changes, and outcome: results of a sequencing study of patients with newly diagnosed myeloma. J Clin Oncol 2015;33:3911-3920. 